DOI: https://doi.org/10.47773/shj.1998.061.1

SCIENCE \& HUMANITIES JOURNAL

VOLUME 6, 2006, PP 1-17

\title{
TREE UTILIZATION PATTERNS IN SELECTED PROTECTED AREAS IN THE VISAYAS
}

\section{TEOFANES A. PATINDOL}

Department of Forest and Wildlife Management and Conservation

College of Forestry and Natural Resources

Leyte State University

Visca, Baybay, Leyte, Philippines

\section{and}

\section{ENRIQUE P. PACARDO}

School of Environmental Science and Management

UP Los Baños, College, Laguna, Philippines

\section{ABSTRACT}

Tree resources in protected areas in the Visayas were mainly used for construction materials and firewood. Inhabitants inside protected areas harvested timber for their own light construction needs and for firewood mostly for household consumption. Illegal harvest of timber for commercial trade was still prevalent but perpetrated by highly influential people staying outside protected areas. Participation of local inhabitants was limited on the transport of lumber from the cutting area to the designated landing sites. Most preferred timber species for construction came from the Dipterocarp family, which are available only in secondary and primary forests. Owing to their being readily available in the locality, exotic species also proved a good source of construction materials. The most preferred firewood species were gap species collected from nearby regeneration areas and woodlots. Local availability and abundance were the primary considerations with respect to preferences for firewood species.

KEYWORDS: Protected areas. Tree species utilization pattern. Preferred timber and firewood species. Lumber transport. 


\section{INTRODUCTION}

Within the framework of sustainable development, protected areas are intended to serve a variety of functions, most notable of which is the conservation of biological diversity resources while recognizing the right of indigenous and local inhabitants to utilize these resources. Resource use in most protected areas is of typical agricultural subsistence economy, supplemented by gathering plants, and occasionally animal and fish products (De Boer and Baquete, 1998). Agricultural productivity in many protected areas is low, which is one of the primary reasons for the importance of natural resources available in protected areas.

Natural resources significantly contributed to different subsistence needs of the rural people. Use of natural resources in protected areas includes harvesting of timber for construction and fuelwood, thatching grass, medicinal plants and a variety of other products. Use of timber for construction purposes was the most important plant use (Wells, 1996).

While it is true that local communities have been exerting continuous pressure on the natural resources in protected areas even before the implementation of the contemporary protected areas management system in the country, information regarding resources use patterns, particularly on timber resources, among local communities is very limited. Resource use patterns may vary with local culture; some may be exploitative in nature, others are conserving. Of equal importance, there is also a need to determine the factors that are significantly associated with resource utilization patterns in order to address the root causes of problems that would have or yet to arise from such patterns of use. Information on these aspects is essential in formulating site-specific intervention strategies that would reduce pressure on resources that are highly vulnerable in order to meet the long-term objectives of biodiversity conservation, at the same time, satisfy the immediate needs of local inhabitants of protected areas. 


\section{METHODOLOGY}

Respondents of the study were selected from three protected areas in Bohol and Leyte. The protected areas include the Rajah Sikatuna Protected Landscape (RSPL) in Bohol, Lake Danao Natural Park (LDNP) and Philippine National Oil Company (PNOC) Geothermal Reservation in Leyte. Eight villages were identified for the study. Six villages were situated inside protected areas while two were situated outside protected areas. Of the six villages situated the inside protected areas, five were in Leyte and one was in Bohol. For the villages outside the protected areas, one was in Leyte and one was in Bohol. The 8 study villages were distributed in Ormoc City and Albuera in Leyte and in Batuan and Carmen in Bohol (Figures 1 and 2). At least $50 \%$ of the households in each village were randomly selected to serve as respondents. A total of 147 household heads were interviewed from the study villages. The distribution of respondents is shown in Table 1.

Table 1. Distribution of respondents by study village in three protected areas.

\begin{tabular}{clcc}
\hline \hline Protected Areas & Village & Number & Percentage \\
\hline RSPL & Bohog & 26 & 18 \\
& Cabacnitan & 20 & 14 \\
LDNP & Lake Danao & 22 & 15 \\
PNOC & Cambantug & 22 & 15 \\
& Cantilong & 11 & 08 \\
& Mahayahay & 15 & 10 \\
& Nueva Vista & 15 & 10 \\
& Tongonan & 16 & 11 \\
\hline \hline & & 147 & 100 \\
\hline
\end{tabular}

The PNOC Geothermal Reservation covers an area of 107,625 hectares in the central cordilleras of Leyte Island. With the primary purpose of geothermal exploration and utilization, the reservation was declared through Proclamation No. 1412 in April 1975. The reservation has important bearing upon the conservation of biodiversity because it contains 
vast areas of the last remaining forest in Leyte Island, which is recognized recently as one of the biodiversity areas in the country that requires urgent protection (Heywood and Watson, 1995).

LDNP is situated inside the PNOC geothermal reservation. It covers an area of 2,193 hectares with a guitar-shaped 140-hectare lake. The park is proclaimed as a protected area pursuant to NIPAS Law by virtue of Proclamation no. 1155 dated February 3, 1998. It is placed under the management category of Natural Park primarily to protect and preserve its outstanding natural and scientific features of natural and international significance for scientific, educational and recreational use.

RSPL, on the other hand, is situated in the province of Bohol. It covers an area of 10,452 hectares of the interior portion of the province. It was designated as a national park on July 10,1987 through proclamation No. 129. On April 23, 2000, it was proclaimed as a protected landscape through proclamation No. 287 and became part of the initial component of protected area network of NIPAS. Prior to its conversion as national park, RSPL has been the core component of Loboc Watershed Rehabilitation Project since the late 1950s.

Primary data were collected by interviewing 147 household heads using a semi-structured interview schedule. To gather more in-depth information, key informant interview were conducted. Secondary data were also obtained from different offices to reinforce the primary data. Standard descriptive statistics were used to analyze the data gathered. Pearson product-moment correlation coefficient was employed to test the association between dependent (lumber transport) and independent variables (age, education, household size, labor force, farm size, farm income, off-farm and total income). 
음-

8

㐘

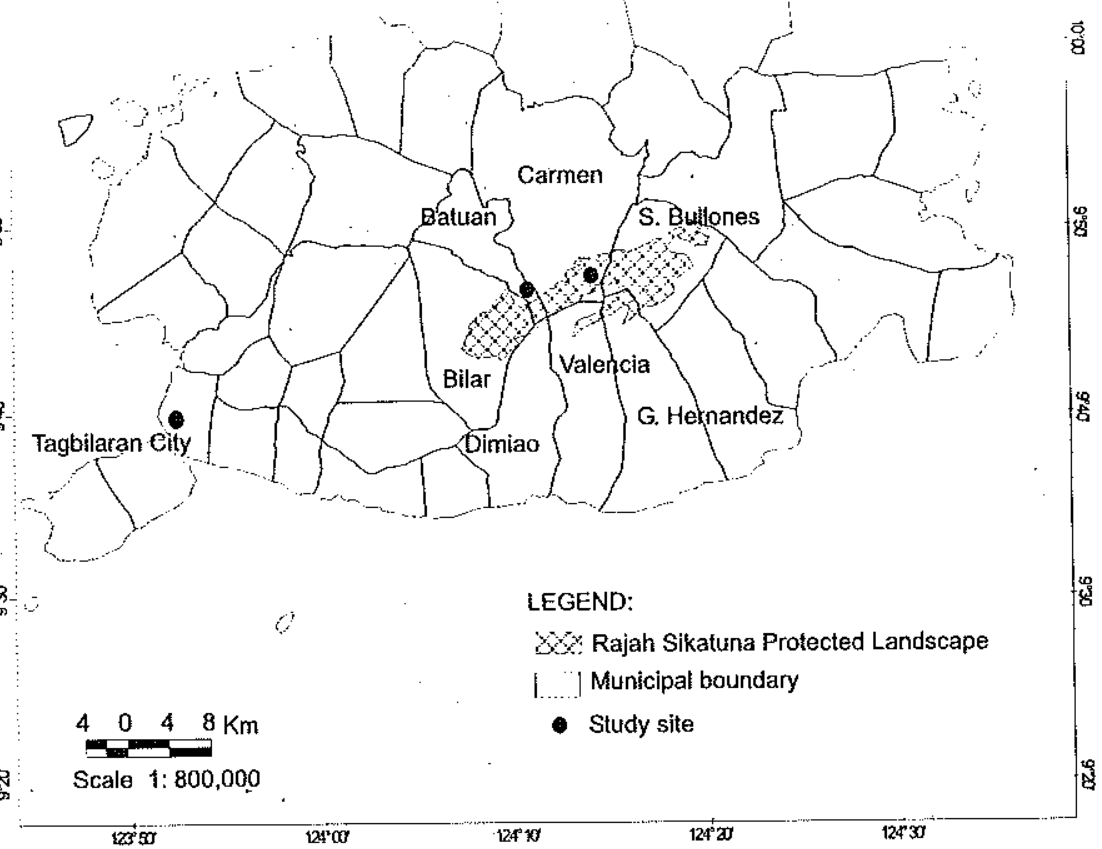

Figure 1. Map of Bohol showing the location of study sites. 


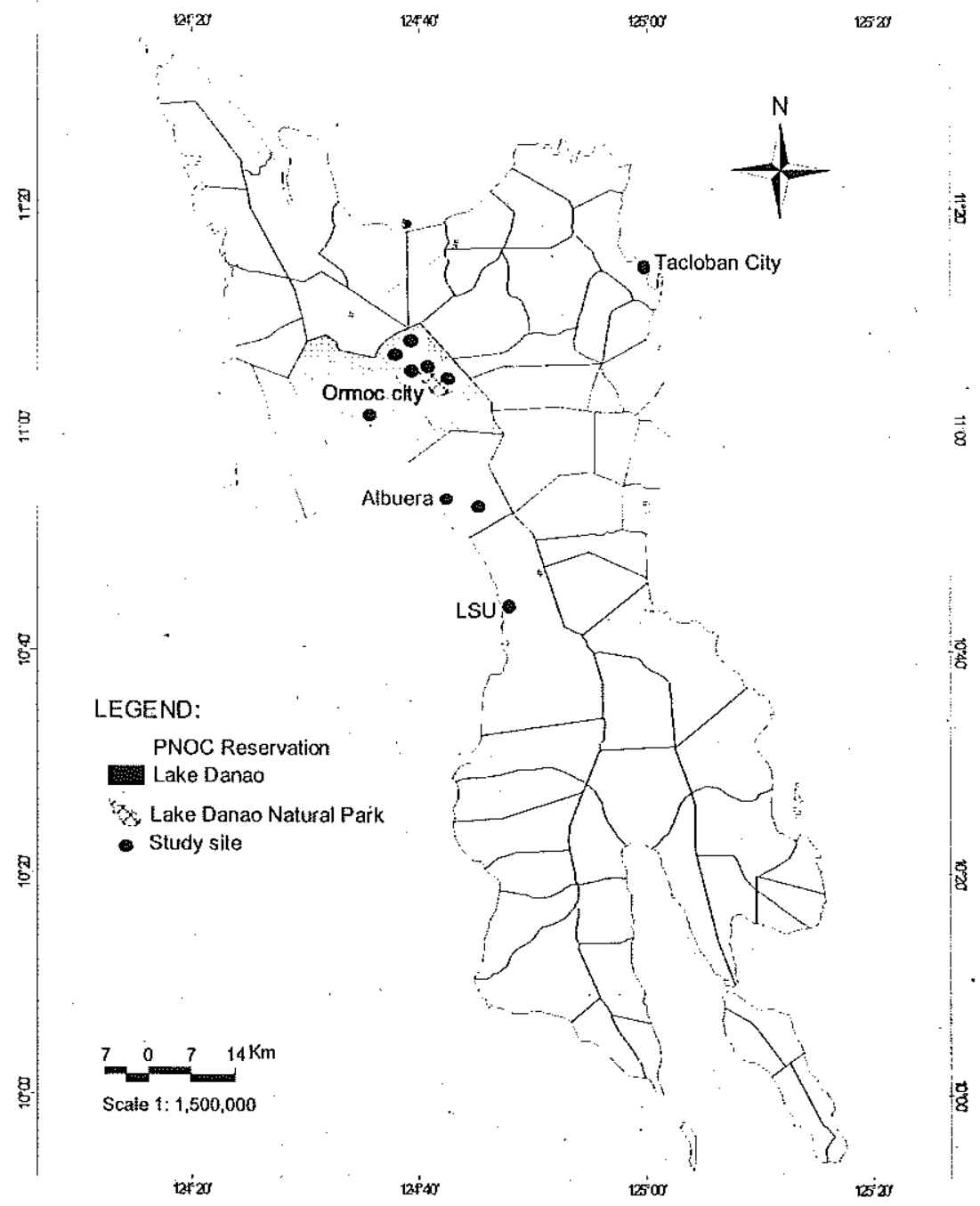

Figure 2. Map of Leyte showing the location of study sites. 


\section{RESULTS AND DISCUSSION}

\section{Tree Utilization Patterns}

Based mainly on motives, two tree utilization patterns were evident inside the protected areas: subsistence and commercial harvesting. Basically in the former, tree products were mostly used for local consumption, while the latter involved trading of the products for cash using an underground market. Tree utilization pattern in most of the study villages was generally characterized as subsistence only. It was entirely associated with the man's basic need for survival. House construction was closely linked to the basic need for protection from the elements as in shelter and firewood for cooking food, another basic need.

Material evidence would show that in recent years, timber products mostly in the round timber forms were still utilized for light construction purposes by local inhabitants. Use of lumber was still observed in most villages as evidenced by wall paneling materials used in most residential houses. Freshly installẹd wall paneling materials mostly come from exotic timber species such as yemane (Gmelina arborea) and mahogany (Swietenia mahogany) harvested from woodlots. Wood paneling materials from commercial timber species could be more associated with old residential buildings. Those materials could have been extracted from the natural forest stands long before the implementation of NIPAS law when timber harvesting was seemingly an unrestricted activity due to low detection rate. Whether in the form of round timber or lumber, these timber materials must have come from the forests inside protected areas. Since time immemorial, collection of timber products from timberland, which became major components of most protected areas, was illegal. But even with the implementation of NIPAS law (RA 7586), timber collection for domestic use of the local inhabitants may be provisionally allowed because of humanitarian reasons. 
Timber harvesting for commercial trade was still evident in the protected areas covered in the study. In fact in one study village, some respondents were actively involved in harvesting timber for trade, which formed part of the highly intricate timber smuggling network operating in the western side of Leyte. Illegal harvest of timber from protected areas was perpetrated by highly influential persons in the locality. Major involvement of protected areas inhabitants was on the transport of lumber from the cutting areas to a landing site outside protected areas. Manual labor was used in the operation to conceal the illegal activity.

As regards firewood, utilization was also limited for household consumption except in one study village where firewood was sold for cash. Firewood however mainly came from the protected regeneration in private lots and not from the forest inside the protected areas. Historically in most study villages, firewood, which came from the forest, was sold for cash. But with strict implementation of the law, the marketing of firewood eventually stopped.

\section{Preferred Timber Species}

Most preferred species for timber was lauan (Table 2). The term lauan as it is applied in most rural settings in the country usually denotes the group of Dipterocarp species mostly of the genus Shorea and Parashorea, which comprise the white and red lauan group dominating the commercial timber market. The next most preferred timber species were apitong and narra. Apitong is also a Dipterocarp species of commercial value for construction purposes. Narra, on the other hand, was not a popular timber species for construction but for furniture. It was preferred probably because it was an excellent paneling material.

Dipterocarp species were generally the most preferred for construction because of their properties like durability, straight grain, somehow resistant to decay and insect attack, and most importantly the relative ease of working with tools. 
The next preferred timber species were nato and molave. These were not Dipterocarp species but somehow had the qualities of the Dipterocarp species. Preference to nato was attributed more on its straight grain, durability and relative ease of working with tools while that of molave was more of its durability. Molave, because of its inherent durability, was also used as material for farm implements in traditional rural society. Mahogany was in the next rank. Not surprisingly, mahogany was preferred because of its good grain, durability and relative ease to work with tools.

Highly preferred timber species were mostly of commercial value and were considered premium hardwood species except nato and mahogany. It should be noted that these species were associated with the natural growth, therefore scarce in second growth and other partially disturbed sites.

Some species were preferred because they were readily available in the locality. Nato, along with apitong, for instance, was preferred by most of the respondents in Cambantug (PNOC) because it was abundant in the nearby forest stand. Most respondents in RSPL also preferred mahogany because it was readily available in the area. Mahogany, being introduced in Bohol as a reforestation species in the 1950s, was the dominant species in privately owned woodlots throughout the entire province.

Results of the study suggest that the most important factor that determined preference to species for timber was the quality of the species as a construction material. Another factor was the availability of the material in the locality. While local communities had the knowledge as regards good quality timber species, they were equally aware where to find the timber species locally. Local communities, given the right chance and opportunity, normally had that inherent tendency to exploit resources.

There was therefore an increasing threat to the remaining Dipterocarp stocks. In Bohog, for instance, a family was chanced upon during the interview sawing a mayapis (Shorea squamata) for lumber inside the house. The lumber was intended for paneling to replace rotten walls of their house. For obvious reasons, the family was able to cut the mayapis from nearby 
forest stand because DENR had withdrawn its personnel from the area due to lack of funds.

Most preferred species were commercial hardwoods usually associated with old and second growth Dipterocrp forests. As population increase was inevitable, an increase of the pressure to our remaining forest as a result of one-sided interaction between forests and local communities would likely happen. In order to divert the attention of local communities away from natural forests, strategies for biodiversity conservation should be designed and carried out.

Promotion of the establishment of private woodlots may be a sound alternative. The massive planting of mahogany in Bohol is a living testimony of the potentials of this activity. Mahogany is now the major source of construction material in the province from private woodlots or plantations. However, it should be emphasized that continued protection work in the protected areas was deemed necessary. Trees would take a considerable time to grow and reach merchantable sizes even if they are fast-growing species. While waiting for the harvest time, illegal logging must account for the lumber needs especially for communities in close proximity to the forest.

\section{Preferred Firewood Species}

Most preferred firewood species by the respondents came from woodlots and protected regeneration areas (Table 3). Ipil-ipil was the most preferred because it was readily available in most areas. Ipil-ipil was introduced in the country as a multipurpose species in the 1980s. It was spreading throughout the study villages in woodlots and protected regeneration along with pioneer tree species. Some local residents were even treating ipil-ipil as a weed species already considering its ability to establish quickly in an area in large number.

Alagasi, agoho, lamay, and binunga were pioneer tree species normally found in protected regenerations. Abundance in the locality was definitely the primary consideration in the selection of firewood species, such that 
the most preferred firewood species vary among the three protected areas. High calorific property, which is sought normally for any firewood species, was only secondary. Another consideration was the ability of the species to re-establish quickly after cutting.

Results suggested that firewood was not a high priority in most study villages because it was generally abundant and available in the locality. Obviously, there is no scarcity in firewood in most study sites as many responded "any dried wood" will do for fuel. Practically, the problem was not in finding fuel but on what to cook on it.

Table 2. Preferred timber species, source and abundance as perceived by the respondents ${ }^{\star}$

\begin{tabular}{|c|c|c|c|c|c|}
\hline Common & Scientific Name & $N$ & $\%$ & $A^{* *}$ & Source \\
\hline Lauan & Shoreasp. & 73 & 49 & $M$ & Old/Second Growth \\
\hline Apitong & Dipterocarpus grandifforus & 28 & 19 & $M$ & OAd/Second Growth \\
\hline Narra & Pterocarpus & 28 & 19 & $\mathrm{R}$ & Old/Second Growth \\
\hline Nato & Palaquium/uzoniense & 21 & 15 & $M$ & OldiSecond Growth \\
\hline Molave & Vitexpaniffora & 20 & 14 & $M$ & WoodlouSecond Growth \\
\hline Mahogany & Swieteniamacrophylla & 18 & 12 & $A$ & Woodlot \\
\hline Hindang & Myricajavanica & 16 & 11 & $M$ & Old/Second Growth \\
\hline Tindalo & Afzeliarhomboidea & $\theta$ & 6 & $\mathrm{R}$ & Old/Second Growth \\
\hline Tagibokbok & Saurauia latibractea & 8 & 6 & $M$ & Old/Second Growth \\
\hline Anislag & Securinega flexuosa & 8 & 5 & $A$ & Regeneration \\
\hline Binluran & Syzygium sp. & 5 & 4 & $\mathrm{R}$ & Old/Second Growth \\
\hline Taguile & Shoreapolysperma & 5 & 4 & $\mathrm{R}$ & Old/Second Growth \\
\hline Tiga & Tristaniopsis micrantha & 5 & 4 & $\mathrm{R}$ & Old/Second Growth. \\
\hline Antipolo & Artocarpus blancoi & 4 & 3 & A & Regeneration \\
\hline Gmelina & Gmelina arborea & 4 & 3 & A & Woodlot \\
\hline Duguan & Myristica philippinensis & 4 & 3 & $M$ & Old/Second Growth \\
\hline Binuang & Octomeles sumatrana & 4 & 3 & A & Old/Second Growth \\
\hline Bagalunga & Melia dubia & 3 & 2 & $M$ & Regeneration \\
\hline Sagimsim & Syzygium brevistylum & 3 & 2 & $\mathrm{R}$ & Old/Second Growth \\
\hline Marang & Lirseaperrottetii & 3 & 2 & $M$ & Old/Second Growth \\
\hline Yakal & Shorea astylosa & 2 & 1 & $\mathrm{R}$ & Old/Second Growth \\
\hline Batino & Alstonia macrophylla & 2 & 1 & M & Old/Second Growth \\
\hline Maksa & Symplocos salix & 2 & 1 & M & Regeneration \\
\hline Gisok & Shoreaguijo & 1 & 0.7 & $R$ & Old/Second Growth \\
\hline Magtalisay & Terminalia foetidissima & 1 & 0.7 & M & Old/Second Growth \\
\hline Teak & Tectona grandis & 1 & 0.7 & A & Woodlot \\
\hline
\end{tabular}

* Multiple response, $n=147$

${ }^{* *}$ Abundanc ${ }^{*} \mathrm{e}: \mathrm{A}=$ abundant; $\mathrm{M}=$ moderately abundant; $\mathrm{R}=$ rare 
Pressure on protected areas from firewood collection may not be as significant as others may think. Because firewood is bulky, transport is very difficult in large quantities. It was therefore reasonably unnecessary that local communities would collect firewood from deep in the forest when there was abundant firewood in the nearby regeneration areas i.e., along the road or in the back yard or at the farm borders. Periodic gathering of firewood in regeneration areas was in itself a form of disturbance that would somehow maintain the species composition in these areas, being successional communities. Under moderate intensities of collection, these regeneration areas would sustainably provide the needed firewood requirement of the local inhabitants. Aside from this, communities situated relatively far from the forest edge were beginning to shift from firewood to gas for fuel.

\section{Correlates of Lumber Transport}

It was learned that illegal timber collection activities were still prevalent in the study sites and were very difficult to control because of their complex network and participation of highly influential figures. Overall, the scenario of timber harvesting in the study sites was also parallel to those elucidated in the expose' of Vitug (1993) such as "Loggers in Congress" and "Soldiers in the Woods". Because the issue was so sensitive and people normally did not reveal illegal transactions, the discussion was limited to lumber transport activities, the major participation of local residents in the highly intricate timber poaching activities in the protected areas.

Members of the Mahayahay Upland Farmers Association in Albuera, Leyte were interviewed for this section. The analysis was limited to this group only because it was a public knowledge that members of this association were all involved in the illegal activities before they joined the association. Thus, they did not have the option to deny or not cooperate with the interview. The association, in the first place, was organized by PNOC although not situated inside its reservation in order to check illegal timber harvesting in the area. Mahayahay was one of the hotspots in the illegal logging activities in the Albuera-Ormoc area. 
Thinking they were no longer active in the illegal transport of lumber, respondents were used as surrogates to those residents who actively participated in the activities. It was found out that some of them were still active in the business. Few respondents admitted that they had to go into the venture again when there would be cash shortage.

Table 4 shows the relationship between selected variables and lumber transport using the Pearson product-moment correlation coefficient. Lumber transport, the dependent variable, refers to the number of board feet the respondent was willing to transport in a weekly basis should there be illegal logging operation in the area. Those who participated in the transport operation were paid on board feet basis, which reflects the volume of timber extracted from the forests inside the reservation. The volume is expressed only in board feet per week because respondents had the difficulty in recollecting data for a year period.

Table 3. Preferred firewood species, source and abundance as perceived by the respondents*.

\begin{tabular}{llrrll}
\hline Common & Scientific Name & $\mathrm{N}$ & $\%$ & $\mathrm{~A}^{\text {**}}$ & Source \\
\hline Ipil-ipil & Leucaenaleuccephala & 37 & 25 & $\mathrm{~A}$ & Woodlot \\
Alagasi & Leucosyke capitellata & 23 & 16 & $\mathrm{~A}$ & Regeneration \\
Agoho & Casuarina equisetifolia & 22 & 15 & $\mathrm{~A}$ & Regeneration \\
Lamay & Mallotus lackeyi & 18 & 12 & $\mathrm{~A}$ & Regeneration \\
Binunga & Macaranga tenarius & 10 & 7 & $\mathrm{~A}$ & Regeneration \\
Gmelina & Gmelina arborea & 9 & 6 & $\mathrm{~A}$ & Woodlot \\
Lanipga & Toona ciliata & 6 & 4 & $\mathrm{M}$ & Old/Second Growth \\
Spiked piper & Piperaduncum & 5 & 3 & $\mathrm{~A}$ & Regeneration \\
Mahogany & Sweitenia macrophylla & 5 & 3 & $\mathrm{~A}$ & Woodlot \\
Dalunot & Pipturus arborescens & 4 & 3 & $\mathrm{~A}$ & Regeneration \\
Hinlaumo & Mallotus ricinoides & 3 & 2 & $\mathrm{~A}$ & Regeneration \\
Kakauete & Glicidia sepium & 3 & 2 & $\mathrm{M}$ & Woodlot \\
Ulayan & Lithocarpus buddii & 3 & 2 & $\mathrm{M}$ & Old/SecondGrowth \\
Balante & Homalanthus populneus & 1 & 1 & $\mathrm{~A}$ & Regeneration \\
\hline
\end{tabular}

* Multiple responise, $n=147$

** Abundance $A=$ abundant; $M=$ moderately abundant; $R=$ rare 
The two variables that showed significant relationship with the lumber transport were age and household size. Both age and household size showed negailive relationship but at different level of significance. This implies that younger respondents were willing to transport more lumber than older respondents. Willingness of course in this case was also reflective of the capacity of the younger individuals to transport based on their physical strength. Younger persons who were at their prime normally can carry more load than their older counterparts especially those at retiring age.

Table 4.Correlation coefficient between lumber transport and selected variables.

\begin{tabular}{lc}
\hline Variables & Correlation Coeffient \\
\hline Age & $-0.221^{* *}$ \\
Education & +0.059 \\
Household size & $-0.162^{*}$ \\
Workforce & -0.046 \\
Farm size & -0.006 \\
Farmincome & -0.019 \\
Off-farmincome & -0.114 \\
Total income & -0.112 \\
\hline${ }^{*} \mathrm{p}<.05 ;{ }^{* *} p<.01$ &
\end{tabular}

Household size showed negative relationship with lumber transport at $5 \%$ level of significance. This means that households with few members would tend to transport more lumber to supplement income from both farm and wage labor. Household with few members had less opportunity to earn more income from wage labor compared to bigger households with many members available for wage labor. In order to compensate their being disadvantaged in terms of number, active household members had to double their effort in the transport venture, which was ideally fit for highly spirited young individuals. 
This finding reflects the most significant role of illegal logging in the area, which was to provide instant cash for the family there being no other sound alternative source of income aside from farming. The farming system in Mahayahay was predominantly of the abaca-coconut intercropping, which cannot provide continuous flow of income for the farmers the whole year round. Abaca was harvested every six months while coconut every three months. When there was no harvest, most residents had no other options but to look for wage labor to supplement farm income. Wage labor in the locality however was so cheap such that many would prefer to transport lumber despite the high risk associated with the work.

Considering that in Mahayahay and in the neighboring barangays already identified as illegal logging hotspots, where income opportunities other than farming were very limited, intervention strategies were designed to put a stop on illegal logging. The strategy of the PNOC of organizing former illegal loggers with the objective of mobilizing them in the detection and apprehension of active illegal loggers was somehow showing an initial sign of success. However, it should be emphasized that livelihood projects had to be provided in a sustainable manner. Few active members of the association admitted that they had to engage in the lumber transport again when time gets tough for them not to rely on the PNOC livelihood projects alone for cash income. Most often members of the association had experienced delay of payments for their labor due to the relatively long billing procedures of the company.

\section{CONCLUSION AND RECOMMENDATION}

Local communities inside protected areas are dependent on timber resources for building materials and firewood. Although officially prohibited, local communities are provisionally allowed to collect these resources for subsistence use only. Premium timber species which are found in old growth forest are the most preferred timber species for construction. Most preferred firewood species were the fast growing which are readily available in regeneration areas. 
Pressure from communities outside of the protected areas, being an important if not the last source, of commercial timber products, is still remarkably evident. The major participation of local communities in illegal logging is on lumber transport from the cutting areas to a designated landing outside the protected areas. Younger respondents tend to transport more lumber especially if there are only few members of the household available to do other forms of livelihood involving wage labor.

Programs designed to reconcile resource utilization and sustainable development in protected areas, which were already in place for more than a decade now, must be implemented sooner. Preventing further degradation of resources and alleviating the well being of the rural poor are both ethically and morally urgent.

Traditional law enforcement of the government must be continued, strengthened and expanded. This means hiring and deployment of additional new forest protection personnel. Community-based park protection must be organized and empowered by means of giving them due recognition and formally decentralizing forest protection to their control. Proper coordination and complementarities must be observed at all times.

\section{LITERATURE CITED}

DE BOER, W.F. and D.S. BAQUETE. 1998. Natural resource use, crop damage and attitude of rural people in the vicinity of the Maputo Elephant Reserve, Mozambique. Environmental Conservation 25(3):208-218.

HEYWOOD, V:H. and R.T. WATSON. 1995. Global Biodiversity Assessment. Cambridge University Press, Cambridge. 1140p.

SIMPSON, S. and S. BUGNA. 2001. Biodiversity Conservation and the Community: A Literature Review and Inputs from NIPAP Experience. Essentials of Protected Area Management in the Philippines, v1. NIPAP, PAWB-DENR, Philippines. 92p. 
VITUG, M.D. 1993. The Politics of Logging: Power from the Forest. Philippine Center for Investigative Journalism: Manila. 277pp.

WELLS, M. P. 1996. The social role of protected areas in the New South Africa. Environmental Conservation 23(4): 322-331.

\section{ABOUT THE AUTHOR}

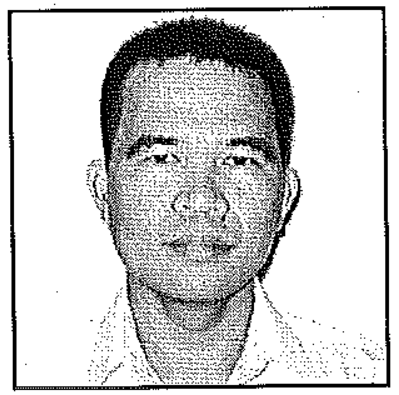

The author earned his Bachelor of Science in Forestry degree (cum laude) from the then Visayas State College of Agriculture (ViSCA), now the Leyte State University (LSU) in 1986. After graduation, he worked as Research Assistant, and in November of the same year, he joined the faculty of ViSCAas instructor.

He obtained his Master of Science in Environmental Studies from the University of the Philippines, Los Baños in 1994 with support from the Enviromental Education Network of the Philippines. He finished his Doctor of Philosophy in Environmental Science, specializing in protected areas planning and management and wildlife studies from the same institution in 2003 with support from the Fund for Assistance to Private Education through the Commission on Higher Education.

He is Assistant Professor of the College of Forestry and Natural Resources, LSU, where he currently teaches courses on ecology, environmental science and wildilife management.

The co-author is a faculty of School of Environmental Science and Management of UP at Los Baños, College, Laguna and is the major adviser of the senior author. 